\title{
Challenges and Boons of Refugee on the Host Communities: In the Case of Benishangul-Gumuz Regional state, Western Ethiopia
}

\author{
Tadele Tesfaye Labiso* \\ Department of Geography and Environmental Studies, Ethiopia
}

Submission: July 25, 2020; Published: September 08, 2020

*Corresponding author: Tadele Tesfaye Labiso, Wolayta Soddo, Department of Geography and Environmental Studies, University College of Social Science and Humanities, Ethiopia

\begin{abstract}
Refugee is a contemporary global issue and the exodus of refugees may potentially conjecture new challenges in the host communities. Ethiopia is a host to the second largest refugee population in Africa. The aim of this study was to explore the challenges and boons refugee the host community who are living surrounding the camp. Specifically the study aimed to identify and the changes that the refugees brought to the host community. The study employed both qualitative and quantitative research approach. In the study, descriptive design was employed. Sample households were determined by using multi stage sampling method. The study employed questionnaires, interviews, document reviewing and discussion with focus groups. On the basis and types of data gathered and the instrument used, both quantitative and qualitative techniques of data analysis or binary logistic regression supported by SPSS were employed. The findings of this research indicated that the refugees in the BGR created actual social and health threats to the members of the host communities. The socio-cultural norms of the host peoples were disrupted in terms of their social insecurity and introduction of health related challenges such as the spread of sexually transmitted infections and other reproductive health problems. As the study indicated that the coming of refugees to this locality has helped the host communities to provide health service, clean water, school and generator that does not exist before. Thus, to improve the lives of host communities and refugee UNHCR and IP supporting agencies should continue to supply the social services to the host communities as before to maintain the hostility between host and refugee community on the social services.
\end{abstract}

Keywords: Refugee; Host community; Boons; Ethiopia

\section{Background of the Study}

Refugees as people crossing international borders in order to escape conflict or Human right violation have been a central focus of international relations. However, the world refugee problem is caused by a variety of reasons which including massive violation of human right, direct and structural violence, war, internal conflict, ethnic and religious strife, direct political persecutions and economic and natural disasters. Likewise, majorities of the mass movements of refugees in the contemporary world are caused by ethnic conflict, natural disasters and shaping of socioeconomic imbalance (Boamah Gyau, 2008).

The Horn of Africa is one of the most conflict prone regions of continent (Kassahun, 2013). For the last 50 years the region has suffered protracted, chronic and complex conflicts and almost all the countries that constitute the region have experienced intraand inter-state conflicts of varying degrees and intensity (ibid).

The eruption of violence in South Sudan in December 2013 placed an additional burden on an already volatile region of eastern Africa, which continues to suffer from conflict and displacement (UNHCR, 2015:5). Therefore, more than 100 million people have become refugees since the beginning of the $20^{\text {th }}$ century as a result of war, revolutions, famine or political boundary changes (McBride, 1991:26).

Nevertheless, the magnitude of refugee influx in recent years has generated urgent concern throughout the world widely perceived as an unprecedented crisis, these flows, have produced a mixture of humanitarian concern for the millions of people 
forced in to expel and fear for the potential threat to the social, economic and political stability of the host states caused by flow of unwanted new comers (Kirui \& Mwaruvie, 2012).

The Government of Ethiopia generally maintains open borders for refugees who are seeking protection in the country. Moreover, the countries those who are bordered Ethiopia facing political, social, economic and environmental challenges which led to the substantial increase in refugees in the country. As of July 2014, a total of 588,000 people from about 13 countries were refugees in Ethiopia. The over whelming majority are Somalis $(242,765)$, South Sudanese over $(217,000)$, Eritreans $(94,000)$, and Sudanese $(34,000)$. Ethiopia also hosts 43,000 refugees from several other countries including Kenya, DRC, Djibouti, and Yemen. Altogether, 59,637 new refugees registered in Ethiopia in June 2014 including 2,565 from Eritrea, 505 from Sudan 1,054 from Somalia and 25,947 from South Sudan (NRC, 2014).

Furthermore, Ethiopia had experienced a large influx of refugees over the last two decades. This is the result of the volatile and conflict condition of the neighboring countries (Sudan, Somalia and Eritrea) in the region of the horn of Africa.

Also, the security problem in Southern Sudan and the conflict between the southern and northern Sudan push civilian out of their home in to Ethiopian border, according to UNHCR's most recent figures, more than 28,000 people crossed in to Ethiopian from Kurmuk, Geissan and other locations on the EthiopianSudanese border in the western Ethiopia (IFRC and RCS, 2011). It is clear that the refugees brought their culture; material and intangible culture, with them. In their interaction with the host community they exchange different cultural aspects, even though there are some ethnic and racial similarity between the refugees and the host community.

\section{Statement of the problem}

It is widely accepted that influxes of refugees into an area can place considerable stresses on natural resources, leading to both environmental and social impacts [2]. The problems associated with refugees may not be restricted to a particular border area but may have spillover effects on the internal security situation of a region. Refugee migration inflicts a significant economic burden on host countries.

The discourse on the impact of refugees on the neighboring and host community is not a new concept to international issues. Globally, a country who received large numbers of refugees faces a variety of social and economic impacts [3].

Thus, the situation in neighboring countries along Ethiopia's western borders has gradually get worse and has become more complex with new tribal fighting adding to internal conflict in South Sudan and ongoing conflicts with the North. This has resulted in increased and even more ethnically mixed and multifaceted populations seeking assistance in Ethiopian regional states along the border, Benishangul-Gumuz in Bambasi refugee camp which found in western Ethiopia (ERCS, 2011).

However, most studies done in western Ethiopia by UNHCR and concerning bodies focused on refugee camps and the needs and problems of the refugees themselves, while the impact that the refugees have on the host community is often considered. Even the existed studies were only about the environmental impact that refugees brought on the host community.

As Atim [4] stated s, refugees upset the ethnic balance in their host countries through what may be thought of as a demographic externality. Ethnic tensions may become especially pronounced when refugees possess ethnic ties with groups already present in the host society.

In countries where ethnic cleavages are deeply entrenched, large unexpected migrant inflows may tilt the delicate ethnic balance in the host society and sparks inter group conflict [4]. Brown further argues that, the sudden influx of refugees can aggravate ethnic problems and changing the domestic balance of power (Brown, 1996:25).

In addition, besides refugee 's flow affect the security and stability of the host country by contributing to organized armed conflict on the territory. The influxes from neighboring states significantly increase the risk of civil war. Therefore, refugee inflows may lead to violent turmoil on the host country 's territory [4].

The sense of exclusion and relative deprivation of local communities generated by provision of aid services to refugees is one of the major drivers of tension and conflict between refugees and host communities. With some exceptions, the focus of the humanitarian support has been on the refugees without paying attention to the host community [5].

The presence of refugees has both positive and negative impacts on the socio-economic of the host community [1]. It is widely accepted that the influxes of refugees could have considerable impacts on natural resources and socio-economic aspects [2].

As Atim [4] stated, refugees upset the ethnic balance in their host countries through what may be thought of as a demographic externality. Brown (1998) further argues that, the sudden influx of refugees can aggravate ethnic problems and changing the domestic balance of power.

Other researchers such as Reggsa (2010) and Dereje (2011) studies focus mainly on the impact of Sudan and South Sudan civil war by fueling ethnics' rivalry in Gambella without addressing comprehensively the impacts of South Sudanese refugees on the host community in relation to the socio-economic, environment and security. Despite the presence of humanitarian organizations reports, little research has been conducted on the impact of refugees on the host community. 
Thus, as Ethiopia is a host for the huge and gradual increasing numbers of refugees, the attention given to the socio-economic impact on the host communities in the country was very limited. However, the socio-economic impact of refugees on the host communities in western Ethiopia has not been studied so far particularly, in the Bambasi refugee camp. Therefore, the study specifically aims to investigate the socio-economic impact of refugees in the Bambasi refugee camp on the host community who are living surrounding the camp.

\section{Objective of the study}

General objective: The overall objective of this study is to explore the challenges and boons of refugee on the host community in Benishangul- Gumuz regional state, western Ethiopia.

\section{Specific objectives}

a) Identify the challenges that the refugees brought to the host community of study area.

b) Investigate positive impact of refugees on the host community of study area.

\section{Significance of the study}

The study will contribute theoretically to the critical issue of refugees' worldwide and empirical evidences of the influx of refugees in Benishangul Gumuz regional state in particular. Since there are scanty literatures, this study will fill the gap in the area under study and provides insights with regard to the overall impacts of refugees on the host communities. The researcher feels that the findings and recommendations made from this study will make the following contributions.

a) It may help to understand the existing realities of refugees on host community.

b) It may give direction regarding the opportunities of refugees on host communities.

c) It may also identify the challenges of refugees on the host community.

d) It may help, NGO`s and Partners (UNICEF) and other stakeholders working on the sector related to refugees to take corrective actions in line with the opportunities and challenges of refugees on host communities. In addition, it may serve as a source of information for other readers who are interested on the issues of refugees.

\section{Delimitation of study}

Currently, benishangul gumuz region has five refugee camps (Bambasi, Sherkole, Tsore, Tongo and Guyo shumbule) hosting South Sudan refugees dominantly. From the five, refugees' camps, three (Bambasi, Sherkole, Tsore) camps are found in Assosa zone. Especially the refugee' camp found in Bambasi Woreda is selected purposively for this study. Furthermore, thematically the study will be delimited to the impacts of refugees on the host communities' who are living around Bambasi refugee camp.

\section{Theoretical framework}

The first objective to be addressed in the research will look closer into the balance of impacts that are affecting the people of the host community of bambasi refugee camp. As the size and diversity of impacts affecting the host community is significantly large, the research will not go into depth on all these impacts, but rather identify the ones of most significant effect. The research will focus on how the camps presence affects the household viability of the local communities in bambasi and how they adapt as a result of the refugee influx. The second objective to be addressed in the research is how these impacts can create opportunity for availability of social service and infrastructure for the host community and refugees. In addition, the research will explore how the same impacts can possibly create collaborations and positive relationships between them. In doing so will the research aim at identifying how to promote coexistence rather than conflict between the two groups.

Literature on the topic confirms that the understanding of these relationships is of high importance as such scenarios are not likely to disappear and where more knowledge of how refugee camps are affecting host communities is needed. To give an overview of how refugee camps may affect host communities have I developed a simplified figure explaining the main features of the relationship and possible outcomes (Figure 1).

\section{Research design and method}

This study is designed in accordance with the principles of mixed research methods. This approach mixes designs (e.g. case study and survey), approaches (i.e. quantitative and qualitative), methods (e.g. questionnaire, group discussion, key informant and observation), sampling techniques (random and non-random) or strategies of data collection (self-administration, face-to-face interview, and mail) and methods of data analysis i.e. quantitative and qualitative (Creswell, 2009). A researcher can mix two or more of these categories according to the purpose and nature of the problem. Choices can be made among case study and survey designs

\section{Population, sampling process and sample size}

The sample refugee camps from which respondents will be selected for the study are selected from Assosa zones. Accordingly, multi-stage sampling method that involves clustering followed by purposive and random sampling techniques are employed to draw the sample. Accordingly, Bambasi 'woreda' is selected purposively. Sample households for questionnaire survey, field facts for 
observations, community members for focus group discussions (FGD) and individuals for key informant interviews (KII) will be

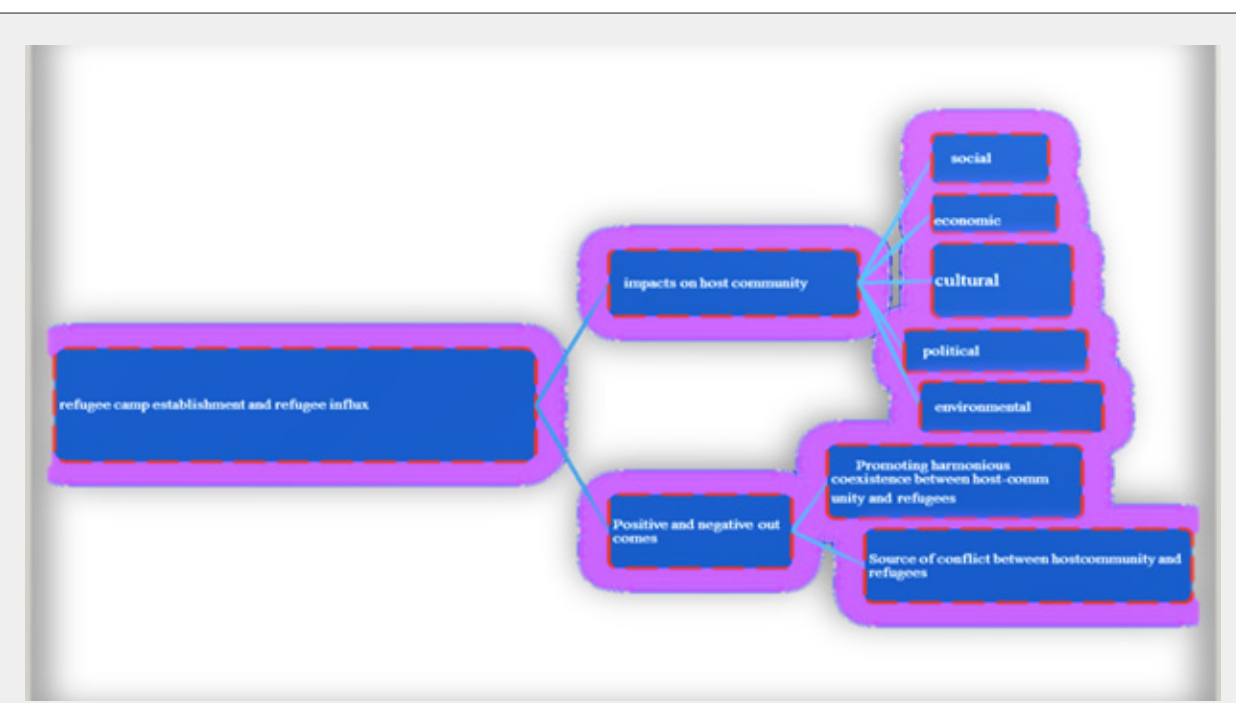

Figure 1: Impacts by refugee camps on host communities.
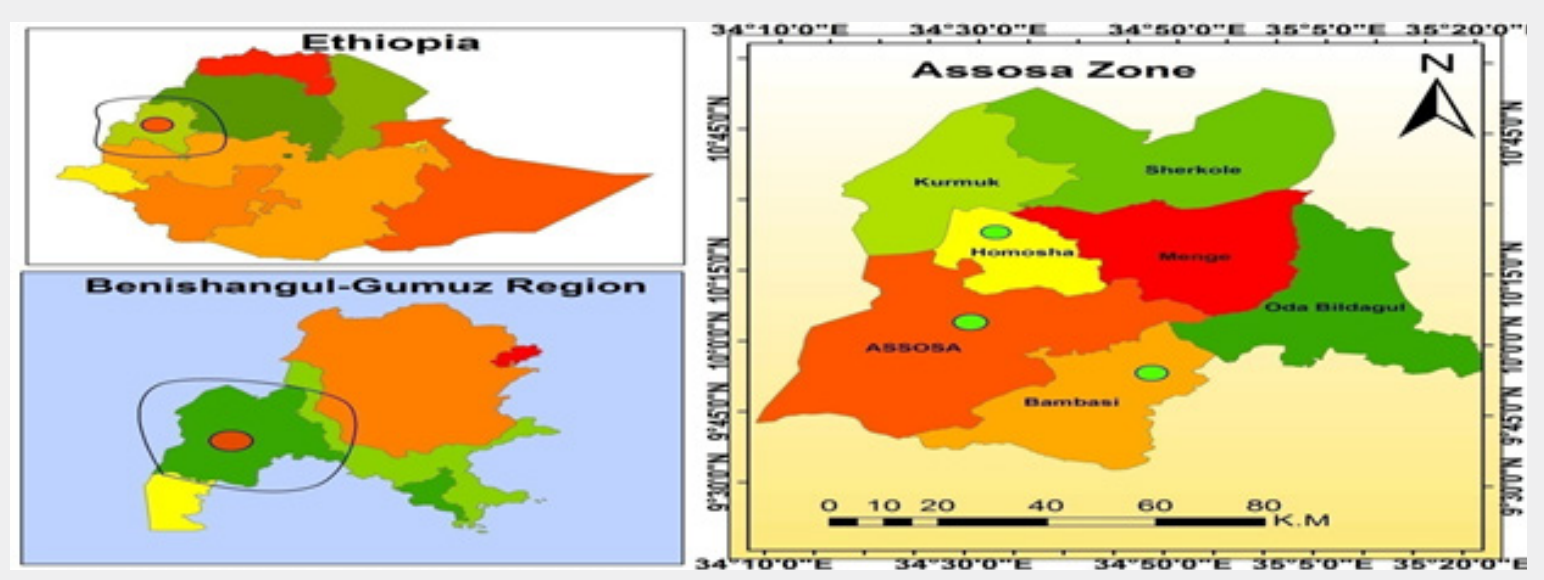

Figure 2: Administrative map of the study area.

The sample frame from which sample respondents were selected was 620 households. Based on the formula suggested by Krejcie \& Morgan (1970), sample size of 124 sample households was determined. The formula and the calculation are given as follows:

$$
S=X^{2} N P(1-P) \div d^{2}(N-1)+X^{2} P(1-P)
$$

Where,

$\mathrm{S}=$ required sample size.

$\mathrm{X}^{2}=$ the table value of chi-square for 1 degree of freedom at the desired confidence level (3.841).

$\mathrm{N}=$ the population size.
$\mathrm{P}=$ the population proportion (assumed to be .50 since this would provide the maximum sample size).

$\mathrm{d}=$ the degree of accuracy expressed as a proportion (0.05).

Table 1 For the purpose of this research, the researcher employed both primary and secondary source of data. The primary sources mainly include empirical data to be gathered by in-depth interview from the study area of local government officials, host communities, refugees and refugee camp staffs. To supplement the primary data the researcher will consult secondary sources such as documents of various organizations, newspapers, magazines, conference papers, monographs and tertiary sources including books and journal articles. 
Table 1: Showing the Sample 'refugee camp' and household size.

\begin{tabular}{|c|c|c|c|c|}
\hline \multirow{2}{*}{ Zone } & \multicolumn{3}{|c|}{ HH Size by 'Woreda' \& Ref Camp } & \multirow{2}{*}{ Sample HH } \\
\cline { 2 - 5 } & 'Woreda' & Refugee Camp & HH Size & \multirow{2}{*}{124 (20\% of total population } \\
\cline { 2 - 5 } & Bambasi & 1 & 620 & 124 \\
\hline \multirow{2}{*}{ Total } & 1 & 1 & 620 \\
\hline
\end{tabular}

Sources: BGRS, IOM, 2019.

\section{Methods of data analysis}

As mixed methods design for data collection, mixed methods of data analysis was employed. The quantitative that will be collected through questionnaire survey and qualitative data that collected through FGDs, KIIs, and field observations was analyzed in a mixed fashion. The quantitative data will be first analyzed and presented and then triangulated with qualitative results.. Before analyzing the data, it was checked for non-response rate, and edited, organized, made ready for entry into SPSS and binary logistic regression was employed. In order to calculate economic welfare loss, we need to use the change in price and the change in quantity demanded of goods and services. The formula to make the calculation is:

$$
\text { Welfare Loss }=0.5 *(P 2-P 1) *(Q 1-Q 2) \text {. }
$$

After data entry is performed, the quantitative data analysis will pass through different stages. Similarly, the data on socioeconomic infrastructure will be analyzed and presented qualitatively and quantitatively.

\section{Result and Discussion}

This chapter has two parts; the first part deals with the characteristics of the respondents; and the second part present the analysis and interpretation of the main data. The objective of the study is exploring socio economic impact of refugee and refugee camp in the host communities, Benishangul Gumuz Regional State Assosa zone bambasi woredas.

There was also discussion on the findings from the fieldwork and presents some of the facts as well as perceptions which offer useful explanations for understanding the socio economic impact of refugee and refugee camp in the study area.

\section{Personal characteristics of respondents}

Gender of respondents: Since the study's focus is socio economic impact of refugee and refugee camp in the host communities, Benishangul Gumuz Regional State Assosa zone bambasi woredas, out of the total of 124 respondents 34 were women whereas the rest $(n=90)$ were male respondents.

Age of respondents: The average age of the household head in the study was $40.1(\mathrm{SD}=10.4)$. The age of the youngest respondent in the study was 18 years old whereas the oldest respondent was 74 years old. The average age for women respondents was found out to be 39.06 years $(S D=9.6)$ whereas that of men was found to be 44.25 years $(\mathrm{SD}=12.6)$.

Educational status: Out of the total respondents 38 per cent are literate (above first cycle) whereas 62 percent are found to be unable to read and write. Out of the male respondents $25 \%$ are literate of which 2 have attended college level school and the rest attended secondary school and below that. Out of women respondent 13 percent are literate in the sample and only two of them completed elementary school the rest are dropouts from elementary school at various levels. No one of the women in the sample attended high school.

Religion: All the respondents are either Christians or Muslim. It was found out that $68 \%$ of the total respondents are Muslims whereas $32 \%$ are Christian. Among women respondents $56 \%$ are Muslim and the rest $44 \%$ are Christian. Of the male respondents $60 \%$ are Muslim whereas $40 \%$ are Christian. However, it is to be noted that strong cultural elements and a set of taboos are strongly adhered to in the community as a whole.

\section{Household characteristics}

Family size: The average family size for the respondent households was found out to be 4.93 (SD=2.27), which is slightly higher than the regional average of 4.7 (CSA, 2007). The minimum family size in the sample respondents was found to be 1 whereas the maximum was 10 persons. The average family size for de facto women head households was $4.52(\mathrm{SD}=2.01)$, whereas the average family size for male-headed households was 6.55 ( $\mathrm{SD}=2.26)$. The age dependency ration was found to be 1.04 which is higher than the regional figure of 0.95 (Regional Statistic and Population Office 2007).

Land holding: The average landholding of the total respondents $(n=124)$ is 1.56 ha. The average landholding of the certain households in one woreda is found to be lower than that of other households of the woreda. Due to shortage of farming land men are pressured to engage in other economic activities and leave their origin (Table 2). 


\section{International Journal of Environmental Sciences \& Natural Resources}

Table 2: average land size of the house hold.

\begin{tabular}{|c|c|c|c|c|}
\hline Average Land Size & Frequency & Percent & Valid Percent & Cumulative Percent \\
\hline below 0.5 hectare & 5 & 3 & 3 & 3 \\
\hline $0.5-1$ hectare & 14 & 16.7 & 16.7 & 19.6 \\
\hline 1-2 hectare & 61 & 54.2 & 54.2 & 73.8 \\
\hline above two hectare & 44 & 26.2 & 26.2 & 100 \\
\hline Total & 124 & 100 & 100 & \\
\hline
\end{tabular}

Source: Survey data, 2019.

Depending on household labor availability and the management capacity of household head, land renting is practiced in the area. Out of the total respondents $(n=124)$ in the study $13 \%$ have reported that they rented out their land during the last production season whereas $5 \%$ reported that they have rented in land in the same year. All those who rented out their land happen to be de facto women heads. Out of those who rented in land only, one of them was a woman whereas the rest four happen to be male-headed households.

Household labor supply: In the study area farm labor is the most critical input in the production process because of the highly labor intensive agricultural production system. In the study area family labor, hired labor and labor sharing arrangements are the most important sources of labor for agricultural activity. Most of the respondent households in the survey have reported that they hire labor for different operation in the farming cycle.

Livestock ownership: Out of the total of surveyed households 90 per cent own livestock of one or the other type. Out of the total households headed by men (75\%) own livestock whereas (15\%) of households headed by women own livestock. The average amount of different kinds of livestock owned by the male and de facto women head households is indicated on Table 3 below.

Table 3: Average animal holding of sample households.

\begin{tabular}{|c|c|c|c|}
\hline \multirow{2}{*}{ Types of Animals } & \multicolumn{3}{|c|}{ Types of Respondents } \\
\cline { 2 - 4 } & All Respondents (n=124) & De Facto Women Head Households 27\%) & Male Headed Households (73\%) \\
\hline Oxen & 0.4 & 0.23 & 1.12 \\
\hline Cow & 1.54 & 1.5 & 1.7 \\
\hline Sheep & 2.1 & 2.03 & 2.3 \\
\hline Goats & 2 & 1 & 2.67 \\
\hline Chicken & 2.38 & 2.29 & - \\
\hline Horses & 0.06 & 0.02 & - \\
\hline Mules & - & - & - \\
\hline
\end{tabular}

Source: Survey data, 2019.

Table 3 indicates that in general terms the male headed households are better endowed with livestock resources than the de facto women head households. This would help them to better cope with unexpected shock in livelihood or to satisfy an immediate cash need by selling animals as is common on the study area Higher number of livestock also means that better access to manure which is quite important for productivity of agriculture on the study area.

Livelihood strategies: Mixed subsistence farming where the crop and the animal sub-sectors are mutually interdependent is the standard kind of livelihood for all households interviewed. All households, however, mentioned that crop production is more important than livestock production to them in terms of immediate food supply and income to the household. Livestock ownership is considered vital for access to manure and as an important means of survival in case of unexpected crises and shock to livelihood due to natural or artificial reasons through sale of the animals as described in previous section.

Agriculture in the study area is highly subsistence-oriented and very few households manage to be self-sufficient in food supply. Out of the surveyed 124 households only 13\% of the households reported that they are food self-sufficient.

\section{Food security status of host communities}

The survey result shows that the majority of the host community members were food insecure. With the exception of key informants selected from different offices, all sources (KKIs with host communities, FGDs and questionnaire respondents) revealed that the community members were generally food insecure. The great majority (i.e. 84\%) of questionnaire respondents reported that establishing refugee camp had not brought significant improvements on their food security and 
livelihood condition. Specifically, $60 \%$ of the total respondents told that food security was better met before the coming refugee in their respective kebele. Although it contradicts with the views

Table 4: Source and amount of food available to sample respondents. of key informants selected from officials, this result goes in line with the FSS measured based on the amount of calories obtained from food produced, purchased and borrowed (Table 4).

\begin{tabular}{|c|c|c|c|c|c|c|}
\hline \multirow{2}{*}{ Food Source } & \multicolumn{6}{|c|}{ Amount produced (in quintal) \& Household Size (ADE) } \\
\hline & Total & $\%$ & Mean & Std & Min. & Max. \\
\hline Cereals & 10342.5 & 83.8 & 30.07 & 21.21 & 0 & 97 \\
\hline Legumes & 523.5 & 4.2 & 1.52 & 8.1 & 0 & 19 \\
\hline Oil seeds & 733 & 5.9 & 2.13 & 7.13 & 0 & 32.5 \\
\hline Vegetables & 364.5 & 3 & 1.06 & 1.23 & 0 & 11 \\
\hline Total Produced & 11963.5 & 96.9 & 34.78 & 22.25 & $\mathbf{0}$ & 97 \\
\hline Grain Purchased & 289 & 2.3 & 0.84 & 2.13 & 0 & 3 \\
\hline Grain Borrowed & 97.5 & 0.8 & 0.28 & 0.15 & 0 & 1.5 \\
\hline Grand Total & 12350 & 100 & 35.9 & - & - & - \\
\hline Grain Sold (GS) & 5204.5 & 42.1 & 15.3 & 6.5 & 0 & 26.5 \\
\hline Seed Reserve (SR) & 402.5 & 3.2 & 1.17 & 1.11 & 0 & 9.5 \\
\hline Grain Lost (PHL) (5\%) & 598.18 & 4.8 & 1.56 & 0.24 & 0.013 & 4.2 \\
\hline Total Deduced & 6205.18 & 50.1 & 13.04 & 5.2 & $\mathbf{0}$ & 63.25 \\
\hline Net Available Food (NAF) & 6144.82 & 49.9 & 17.86 & 10.2 & 0.01 & 42.5 \\
\hline Household size (number) & 2301 & - & 6.68 & 1.53 & 1 & 13 \\
\hline Household size (ADE) & 1785.88 & - & 5.19 & 2.13 & 1.25 & 10.18 \\
\hline Ave. NAF/ADE/year & 3.44 & - & 1.31 & 2.78 & 1.02 & 13.52 \\
\hline
\end{tabular}

Source: Survey data (own observation), 2019.

According to the results in Table 4, the per capita crop yield for all respondents before deducing all the necessary deductions was 6.69quintal/ADE/year showing that on average all households were food secure. This was in line with the information obtained from settlement and food security departments of all sample 'respondents' which shows all households were food secure in the kebeles. However, calculation of the net available food after necessary deduction was 1.31quintal/ADE/year showing on average the host communities are still food secure according to FAO recommendation. But the calorie indicator shows that the majority (i.e. about 67\%) of households were food insecure which contrasts with the measurement given by food security department of all sample 'households' where host communities were $100 \%$ food secure.

Table 5: Shows social impact of refugees on the host communities.

\section{The social impact of refugees on the host communities}

(Table 5) According to the data obtained from both the interview and focus group discussion, the social and cultural interactions and relation of refugees of Bambasi camp and the host communities have two forms. On the one hand the local host community and refugees of Bambasi camp have many social and cultural elements that the two groups share in common which played a role for the peace full co-existence of the groups. On the other hand, there are some activities of refugee which contributing to the social sick of the local community due to the presence of them in the area. However, as the study participant indicated that both the host and refugee communities have many socio-cultural elements in common that strength their social relation and their peaceful co-existence.

\begin{tabular}{|c|c|c|}
\hline Is there any social impact of Refugees on the Host Communities? & Number of Respondent & Percentage \\
\hline Yes & 100 & 81 \\
\hline No & 12 & 9.67 \\
\hline Not certain & 12 & 9.67 \\
\hline Total & 124 & 100 \\
\hline
\end{tabular}

Source: Survey data (own observation), 2019. 
As the respondents from the local community point out that because of the existence of these better social interaction and relation between the refugees and the local host community, members of the local host community acquired some social elements and skills from the refugee community that do not exist before. The daily interaction of the local communities with the refugees gave them the opportunity to learn how to speak English language in addition to Arabic language. Local communities are also acquired hard working from refugee that, they are producing production at the summer season in their small garden. At the same time local communities are acquired their motivation and attitude they have for education.

\section{The impact of refugees on social services}

(Table 6) As the participants from the host community

Table 6: Shows impact of Refugees on Social Services. indicated that the coming of refugees to this locality has helped the host communities to provide health service, clean water, school and generator that does not exist before. Here in the case of health center there was no equipped and organized health institutions that give service for the patient before the presence of refugees in the area. But now a day with no limitation the health center gives significance number of service for patients of the host community coming from different parts of the area to make use of this free health service. Also, as most respondents indicated patient with health problem including mother during delivery capacity of the health center always referred to the Assosa hospital freely without any payment. As the study participants indicated from the host community, school is also another social service that is provided as a health center for the local communities.

\begin{tabular}{|c|c|c|c|}
\hline Is there any impact of Refugees on Social Services? & Number of Respondent & Percentage & Remark \\
\hline Yes & 110 & 88.7 & \\
\hline No & 5 & 4.83 & \\
\hline Not certain & 9 & 7.25 & \\
\hline Total & 124 & $100 \%$ & \\
\hline
\end{tabular}

Source: Survey data (own observation), 2019.

As the respondent showed that, similar to other social services, water is also constructed for the local community by IRC and UNHCR. IRC is constructed borehole and denoted for every kebele who are nearest to the bambasi camp. All of the water boreholes are currently functional and providing the host community of these area with clean water service. Beside to the construction of clean water service, IRC provide WASH related awareness rising and educational service to the local host community.

\section{The economic impact of refugees on the host communities}

Table 7: Shows Economic Impact of Refugees on the Host Communities.

\begin{tabular}{|c|c|c|c|}
\hline Is there any Economic Impact of Refugees on the Host Communities? & Number of Respondent & Percentage & Remark \\
\hline Yes & 110 & 88.7 & 4.3 \\
\hline No & 5 & 7 & \\
\hline Not certain & 9 & $100 \%$ & \\
\hline Total & 124 & \\
\hline
\end{tabular}

Source: Survey data (own observation), 2019.

(Table 7) The data obtained from the survey, interview, focus group discussion and filed observation showed that, local communities are benefited due to the presence of the refugees in the area that they are selling their product to the refugees and at the same time buy different goods and services from the refugees. Also, there is high scale flow of relief food and material aid for the refugees. This aid engulfs the market and has devastating impact on the local products of good and service in the market. Similarly, some of the educated and non-educated people are able to get employment by the aid agencies.

As respondents showed, at the same time before the coming of refugees in the area, the local communities are not producing the production for the market and also the price of the production was not high as today. After the influx of the refugees to the area, there is the change of the price of the production. According to the respondents who are employed in the implement partner to serve the refugees, there is the high change of the price of different goods and services in the recent time in this area. The increment of the price of items is enabling the producer to produce more than before. This is because to have better income from the production. For example, the one who rear goat is doing more because refugees are used goat for feeding. This helps the local people to increase their own income. Therefore, the price of items and products used for consumption are highly increased because 
there is high amount of people and consumer who used it. So, the supply and demand are not balanced.

\section{Changing livelihoods due to the establishment of refugee camp}

(Table 8) As the survey result indicates, providing livelihoods before the refugee presence is explained by all respondents as extremely challenging. Several respondents from the villages of bambasi Woreda described the situation as featured by "no food, no income and no sustainability". Eating wild fruits collected from far away and digging in the river for water was the main source of surviving for the great majority of the host community respondents. Respondents from wemba villages (bambasi Woreda)) explained that they could go starving for days without food, some even died of starvation according to the respondents.

Table 8: Shows Changing livelihoods due to the establishment of refugee camp.

\begin{tabular}{|c|c|c|c|}
\hline $\begin{array}{c}\text { Have experienced any Change in livelihoods due to the establishment of } \\
\text { Refugee Camp? }\end{array}$ & $\begin{array}{c}\text { Number of Respon- } \\
\text { dent }\end{array}$ & Percentage (\%) & Remark \\
\hline Yes & 60 & 48.3 & \\
\hline No & 55 & 44.35 & 7.35 \\
\hline Not certain & 9 & 124 & \\
\hline Total & 124 & \\
\hline
\end{tabular}

Source: Survey data (own observation), 2019.

The majority of the respondents identified that they have experienced some small changes. The most reported change in providing livelihood is that the refugee camp has created a larger market for them to sell items such as firewood, charcoal and others. In addition, the camp presence has created new job opportunities for hosts. The creation of new market and job opportunities improved their situation to some extent in terms of providing livelihoods. The majority of the respondents are still facing great challenges in their daily lives and struggle to provide livelihoods for their families.

Table 9: Shows patterns of adapting to the new realities.

\section{Adapting to the new realities}

(Table 9) As the information from discussant indicates, adapting to new realities accompanied by the refugee camp presence has brought changes for some. Some of the respondents identified that they have experienced some improvement on the individual level. The changes explained by the respondents mainly relate to the fact that they have experienced some improvements in terms of accessing the camp for providing livelihoods through work, business and trading. The remaining the respondents argues that the new opportunities are limited and still face similar challenges and have no sustainability in providing livelihoods.

\begin{tabular}{|c|c|c|c|}
\hline Have you experienced New Realities? & Number of Respondent & Percentage \% & Remark \\
\hline Yes & 100 & 80.64 & 7.25 \\
\hline No & 9 & 12 & \\
\hline Uncertain & 15 & $100 \%$ & \\
\hline Total & 124 & \\
\hline
\end{tabular}

Source: Survey data (own observation), 2019.

\section{Environmental impacts of refugees on the host community}

All informants replied that there is still a devastating impact of refugees on the forest in the region. This posted a serious problem to the host community who depend on the forest for their livelihoods. Another impact of the refugees on the environment is loss of wild animals and plants on which the people relied on for food. This environmental impact can be observed from the loss of wildlife population from Ambessa forest which was known in the past for its large number of wildlife population. This implied that the presence of refugees has negative environmental impact on the host community.

\section{Hosts relationship with the refugee population}

(Table 10) As the survey result shows, the largest group of respondents $(70.96 \%)$ is stating that situations of conflict, violence and hostility between hosts and refugees are common. At the same time the respondents in this group have also experienced personal relationships with refugees that have not been problematic. Therefore, respondents in this group have described their relationship as unbalanced. Several of the 
respondents further describe the relationship as unpredictable where they sometimes can work together and sometimes conflicts starts between them. Conflicts between hosts and refugees were more frequent in the past according to several of the respondents

Table 10: Shows hosts relationship with the refugee population.

\begin{tabular}{|c|c|c|c|}
\hline Hosts relationship with the Refugee Population & Number of Respondent & Percentage & Remark \\
\hline Positive & 20 & 16.12 & 70.96 \\
\hline Negative & 88 & 12.82 & \\
\hline uncertain & 16 & $100 \%$ & \\
\hline
\end{tabular}

Source: Survey data (own observation), 2019.

Respondents from all villages explain a common situation where many individual conflicts between locals and refugees take place. Many people from the host community approach the camp in search for food and water which themselves are lacking. The perception from the majority of the respondents is that this is an area where disputes and conflicts between locals and refugees often start for different reasons.

Several respondents from the villages describe that conflict situations often take place when locals are working for refugees. It can be dangerous especially for women to go to the camp looking for work or selling items such as firewood. Women can easily be assaulted, exploited, raped and even killed if they are in the camp by themselves according to the respondents.

Two respondents from the village explained that disputes often start when locals are working for refugees and they disagree over the amount of food or money they are supposed to be paid. One of the respondents further adds that refugees often ask them "why they have to go to the camp and look for food and why their government does not assist them". The same respondent explains that this is a common situation for many in the host community as they struggle to survive and therefore go to the camp looking for work and food. This is also an area where conflicts often start according to the respondent.

\section{Discussion of the Result}

In all the study considers the impact of the presence of refugees on the host community who are living surrounding the bambasi refugee camp. Notably, the study makes the discussions on the socio-cultural and economic impact of refugees on the host community of bambasi camp. Particularly, the host communities are benefited from the presence of refugees in the areas of social service, health care, education, clean water and sanitation. With this the study makes remarks on the discussion done.

The finding of the study shows that the presence of the refugees in bambasi camp in western Ethiopia has substantial social impact on the surrounding host community. According to the study the impact has both positive and negative like the in this group. Four of the respondents in the host sample have only negative experiences (problematic) with refugees in Bambasi.

study conducted in different parts of the world. As finding of the study indicated that both host and refugee communities share social and cultural elements in common that make strong their co-existence. Due to the positive social and cultural interaction between host and refugee communities, refugees borrow different kinds of things including animals from the host communities. Moreover, host communities and refugees are celebrated national and international holiday like world environment day and world refugee day. As a matter of chance, the host community reflected their own culture and value to the international communities.

As finding of the study shows that, refugees are disturbing peace and security by making hostility with the local community on the utilization of natural resources. Refugees are also the cause for the prevalence of prostitution in the area which pave the way for HIV/AIDS and other sexual transmitted disease. Mostly refugees are claimed by the local community for their incidence of crime related to rape, promotion of drug addiction like shish/hash, chate, alcoholism, cigarette and others. As a result, the local youth are adopted the conduct from refugees. Likewise, the stealing and robing activities of the refugees badly harm the host communities and there are the youth who are participate and support refugee the action which do not exist before.

The presence of refugees in Bambasi refugee camp of western Ethiopia has economic impacts on the host community. As the finding of the study show that, the presence of refugee camp in Bambasi has both positive and negative impact on the host communities who are living surround the camp as similar to the social one. In this situation the host communities have access to buy oil food and aid items by the low price from the refugees. Likewise, refugees are selling their own aid items for the exchange of different goods and services. At the same time refugees are sell to the local communities' plastic sheet, blanket, metal and other materials by the low price. Similarly, as the study conducted by UNHCR (1997), on Social and economic impact of large refugee populations on host developing countries, showed that, the presence of refugees benefited the local people through the local purchases of food, non-food items, payment by the aid workers, the 
properties brought by refugees themselves as well as employment and income increased to local population directly or indirectly. On the other hand, the economy of the area is increased the cost of living within the community that, food and other commodities are become very expensive.

Likewise the study conducted by Whitaker (2002) on Refugees in Western Tanzania; the distribution of burdens and benefits among local host, realized that the presence of refugees increased food security in local village and even after they started to receiving ration, they continued to depend on local crops for the diversification of their diets [6-21].

Conclusion and Recommendation

\section{Conclusion}

The study was carried out with broader objective of assessing the socio-economic, impacts of refugees on the host community in Bambasi woreda. One of the peripheral regions of Ethiopia, BGR, has been predominantly characterized by presence of large but also ever-increasing number of refugees from South Sudan.

The overall findings in this study leads to general conclusion that the massive presence of refugees have more of negative implications than positive gains on the host community. Economically, the presences of refugees have both positive and negative impacts on the host community. Some of the positive economic impacts for the host communities included creation of new employment opportunities to the host communities, diversification of production and commercialization of local goods.

The study also revealed that refugees have negative impact on both environment and security on the host community by the destroying the forest and other natural resources and fueling the ethnics' tension in the region.

It is clear that the refugees who are in Bambasi camp are crossing international border and come to settle in the camp. The arrivals of these refugees impact the social and economic situation of the host communities positively and negatively. However, refugees and host communities of Bambasi camp have share social and cultural elements that make them to live together easily. They have similar language and religion which help them to have better communication. Due to the presence of better communication, host communities acquired knowledge and skills from the refugees. They developed language skills, hardworking, motivation and attitude for education from refugees.

Furthermore, Refugees are buying different necessities like cloth, vegetables, fruits and others from the market. This is a means of an income for the host communities who are supplying them to the market. There are the refugees who rent their labor to earn an income and receive remittance from abroad. By using these, they purchased large amount of locally produced food items which resulted in an increment of the price of food items in the market. There is also the change of the price of items in the market due to the presence of high consumer and insufficient production supplied to the market. This is caused the shortage of locally produced items. This is also cause competition between refugees and host communities on the consumption of the local production.

These competitions led to the increment of the price of goods and services in the area. There is also the dramatic change of the price of food and non-food items around the shop in the area. The dramatic change prices of the items are the result of high influx of refugees and other people who are employed in the supporting agencies. Therefore, the increment price of items in the market is positive for producers who supply it to the market and in the contrary, it is negative for the buyers and consumers. Due to the increment of the price of production the one who engaged on production produce more to maximize their own profits.

\section{Recommendations}

Based on the findings and analysis of this study and how to improve concerning issues faced by both host community and refugees. In their effort to address refugee problems, policies of national government and international organizations should be holistic enough to easier the burden refugees place on host community.

a) The humanitarian organizations should be able to distinguish different categories among host communities, especially those who are poorer, more vulnerable and more likely to be hurt by refugee competition just as the case in BGR, Ethiopia.

b) ARRA should strongly control the local youths who are developed drug addiction and participate to theft and robbing with the refugees.

c) In this way durable solutions would be sought to mitigate if not eradicate the negative implications for the host communities.

d) Another major strategy to mitigating the impact of refugee situations on host communities is the concept of burden sharing. This is when the international and donor agencies acknowledge the burden refugees place on host countries.

e) Repatriation of refugees to their original country is the best option ever, since the pushing factor for refugee flight might civil war, natural disasters and war are not elongated problem.

f) Ethiopian government should reform camp policies which necessarily defend the social and economic condition of the local communities who are living around the camp.

g) Satellite organization of united nation should strongly control the robbing behaviors of the refugees by making strong relation with the local leaders. 
h) UNHCR and supporting agencies should increase their support and diversified the food and non-food aid.

i) UNHCR and IP supporting agencies should continue to supply the social services to the host communities as before to maintain the hostility between host and refugee community on the social services.

j) The supporting agencies also should supply the alternative means of energy and build the home of the refugees by other material rather than grasses to maintain hostility on natural resources.

\section{Acknowledgement and Author Profile}

\section{Acknowledgement}

Above all I would like to thank the Almighty God for his unreserved gift. First and foremost, I want to express my gratitude to research participants including my wife Tinsae Abraham Bassa whom I am duly bound to express my gratitude. They devoted their precious time and energy to comment on and improve the progress of the study since its initiation. Without their guidance and professional expertise, the completion of this work would not have been possible. I am indebted to Assosa University research and community service directorate and large number of individuals for their encouragement and help while conducting this study.

\section{Author Profile}

Mr. Tadele Tesfaye Labiso, is a graduate of Bachelor of education in geography and environmental studies from Samara University, Ethiopia in 2010/11. He persude Master of Art in Socio economic development planning from Dilla university ,Ethiopia in 2017/18 .Currently he is full time instructor in wolayta soddo university in the college of Social Sciences and humanities in the Department of geography and environmental studies. He has published more than six research papers in both local and international reputable journals and attended national and international conferences for the past few years while serving the academic community. His research interest includes population geography, demography, refugee, migration, livelihood and education. He has 10 years of teaching experience and 5 years of research involvement.

\section{references}

1. Berry L (2008) The Impact of Environmental Degradation on Refugeehost relations: A case Study from Tanzania. University of Denver, Colorado, USA.

2. Martin A (2005) Environmental Conflict between Refugees and Host Communities. School of Development Studies. Journal of Peace Research 42(3): 329-346.

3. Jacobsen K (2001) The forgotten Solution: Local integration for refugees in developing countries. New issues in refugee research working paper.
4. Atim G (2013) The Impacts of Refugees on Conflicts in Africa. Institute for Peace and Conflict Resolution Abuja. IOSR Journal Of Humanities And Social Science 14(2): 04-09.

5. Dereje Feyyisa (2014) The spillover effect of South Sudan in Gambella, in Horn of Africa Bulletin. Journal of Life and Peace Institute.

6. Betts A (2009) Development Assistance and Refugees, Towards a North-South Grand Bargain? Forced Migration Policy Briefing. Refugee Studies Centre, University of Oxford. United Kingdom.

7. Bizune Beyene (2006) Historical and Political Origins of Conflict in the Gambella Region. Journal of Oromo Studies.13(1 \& 2).

8. Borchgrevink A, Lie JHS (2009) Regional Conflict and International Engagement on the Horn of Africa. Norwegian Institute of International Affairs.

9. Callmard A (1994) Refugee and Local Hosts: A Study of the Trading Interactions between Mozambican Refugees and Malawian Villagers. Journal of Refugee Studies 7(1): 39-62.

10. Cascão AE (2013) Resource-Based Conflict in South Sudan and Gambella (Ethiopia): When Water, Land and Oil Mix with Politics. Center of African Studies (CEA)/ISCTE-IUL, University Institute of Lisbon, Lisbon.

11. Chambers R (1986) Hidden losers? The Impact of Rural Refugees and Refugee Programs on Poorer Hosts. International Migration Review 20(2): 245-263.

12. Collins JS (1996) An Analysis of the Voluntariness of Refugee Repatriation in Africa. University of Manitoba.

13. Crisp J (2001) Ming the Gap! UNHCR Humanitarian Assistance and the Development Process. International Migration Review 35(1): 168-191.

14. Deikun G, Zetter R (2010) Meeting Humanitarian Challenges in Urban Areas. Migration Review issue 34, February, University of Oxford. United Kingdom.

15. Dereje Feyissa (2006) Decentralization as Ethnic Closure, with Special Reference to a Declining Negotiated Access to Natural Resources in Western Ethiopia. Africa Development 31(2): 243-260.

16. Dereje Feyissa (2010) The cultural construction of state borders: the view from Gambella. Journal of Eastern African Studies 4(2): 314-330.

17. Dusenbury A (2013) Post-Conflict Returnee Reintegration: A Case Study of South Sudan and the Livelihood Approach. Naval Postgraduate School George.

18. Gomez MP, Christensen A (2010) The impact of refugees on neighboring countries: A Development challenge. World Bank. Washington, D.C., U.S.A.

19. Grinvald M (2010) Problems of Integration of Refugees and Internally Displaced Persons in Serbia. Palacky University.

20. Miriam (2009) Sri Lankan Tamil Diaspora: Contextualizing PreMigration and Post- Migration Traumatic Events and Psychological Distress. University of Toronto, USA.

21. Dusenbury AS (2013) Post-Conflict Returnee Reintegration: A Case Study of South Sudan and the Livelihood Approach. Naval Postgraduate School George. 
(C) This work is licensed under Creative DOI:10.19080/IJESNR.2020.25.556171

\section{Your next submission with Juniper Publishers} will reach you the below assets

- Quality Editorial service

- Swift Peer Review

- Reprints availability

- E-prints Service

- Manuscript Podcast for convenient understanding

- Global attainment for your research

- Manuscript accessibility in different formats ( Pdf, E-pub, Full Text, Audio)

- Unceasing customer service

Track the below URL for one-step submission https://juniperpublishers.com/online-submission.php 